\title{
大量の排膿を認め診断に難渋した化膿性脊椎炎の一例
}

宮崎医科大学整形外科学教室（主任：木村千伋教授）
川 野 桂一郎・田 島 直 也
木 下 泰 行・税 所 幸一郎
木 村 千 伋

\section{Pyogenic Infection of the Spine with a Psoas Abscess which Discharged Large Quantities of Pus}

-A Case Report_—

by

\author{
K. Kawano, N. Tajima, Y. Kishita, K. Saisho \\ and C. Kimura
}

Department of Orthopedic Surgery, Miyazaki Medical College.

\begin{abstract}
A female aged forty-eight had suffered severe low back pain in June '82 without any trauma. She had an attack of apoplexia in past history. Radiographic examination of the spine showed osteolytic changes of the 3rd and 4 th lumbar spines, and tuberculous spondylitis or spinal tumor was suspected. In November ' 82 , she was admitted to our hospital complaining of the symptome of acute renal insufficiency. Four days later, she had the inflammatory change resembling phlegmone around left low back region and was drained a large amount of pus with puncture. ESR, WBC and CRP were noted to be abnomal. Tuberculin test revealed negative. In December 1982; also abscess formation was manifested around the left-hypoabdominal region, and 330 grams of pus was drained. After all, the fistula closed a month later. Needle biopsy showed chronic inflammation but the bacterial culture from the 3 rd and 4 th lumbar spine was negative. Antibiotics therapy and surgical therapy by anterior fusion led to a good prognosis.
\end{abstract}

\section{はじめに}

近年，カリエスも見直されているが，一方，化膿性 㝓椎炎の増加が 目立っている. しか子化膿性脊椎炎 は, 近年の抗生剂の発展に伴って, その病態は種々の 形をとり，脊椎カリエスや春椎腫瘍との鑑別に困難を 覚える場合も少なくない，最近，我々は左腹部・腰部 に膿瘍を形成し, 切開により大量の排膿を認め, 診断 に難泳した化膿性脊椎炎の一例を経験したので報告す る.

\section{症例}

患者：48 歳, 主婦

主訴：腰痛
家族歴：母親が直晹癌で死亡

既往歴：昭和 45 年, 脳卒中（右片麻疩）

現病歴：数年来, 誘因なく軽度の腰痛を訴えていた が昭和 57 年 6 月, 臥位にて突然激しい腰痛が出現, 近医入院し鎮痛剂投与を受けるあ軽快せず，同年 8 月 当科を紹介された．単純レ線像にて，春椎腫瘍及び脊 椎の炎症性疾患が疑われたが，本人の希望により，近 医にて入院加療. 同年 11 月 19 日, 急性腎不全の状態 となり当科に緊急入院.

入院時所見：体温 $37.1^{\circ} \mathrm{C}$. 腰痛強く, 臥位にてあ 軽快せず同一体位保持が困難である. 左腰部に $10 \mathrm{~cm}$ $\times 5 \mathrm{~cm}$ の腫脹があり, 軽度発赤, 熱感も認めた。下 肢に腱反射六進, 病的反射陽性など神経学的異常所見 を認めたが，脳卒中による残存症状と思われた．また 
尿量は 1 日約 $100 \mathrm{cc}$ と著明な減少を認めた.

臨床検查所見：表一 1 亿示した如く，高度の腎不全 の状態と炎症所見が認められる。なおア「「」は 18.6 と高值を示した. ッ反は（一）であった.

$\mathrm{X}$ 線所見：単純 $\mathrm{X}$ 線側面像で, $\mathrm{L}_{4}$ 椎体前上縁に半 円状の骨融解像之同部前方より $\mathrm{L}_{3}$ の椎体下隅まで延 びる骨棘形成を認める，骨融解像周囲には，僅かに淡 い反応性骨硬化を認める（図一 1).

断層撮影にてむ, 図一 2 の如く骨融解像は明瞭であ

表1 アンダーラインは異常頕を示す.

(臨床検查所見)

\begin{tabular}{|c|c|c|}
\hline \multicolumn{3}{|l|}{ 末梢血液所見 } \\
\hline $\begin{array}{l}\text { WBC } \\
\text { RBC } \\
\text { Hb } \\
\text { Ht } \\
\text { 血小板 }\end{array}$ & \multicolumn{2}{|c|}{$\frac{\frac{18.4 \times 10^{3}}{2.43 \times 10^{6}}}{\frac{6.9 \mathrm{~g} / \mathrm{d1}}{23.0 \%}}$} \\
\hline \multicolumn{3}{|c|}{ 赤血球沈降速度 } \\
\hline $\begin{array}{l}60 \text { 分 } \\
120 \text { 分 }\end{array}$ & $\frac{150 \mathrm{~mm}}{181 \mathrm{~mm}}$ & \\
\hline \multicolumn{3}{|c|}{ 血清学的兔疫反応 } \\
\hline CRP & $(6+)$ & \\
\hline \multicolumn{3}{|l|}{ 原所㫕 } \\
\hline $\begin{array}{l}\text { 簿 } \\
\text { 算 } \\
\text { 潜血 }\end{array}$ & 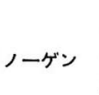 & $\begin{array}{l}(-) \\
( \pm) \\
( \pm) \\
\end{array}$ \\
\hline
\end{tabular}

血清生化学所見

\begin{tabular}{|c|c|}
\hline $\begin{array}{l}\text { A } / \text { G } \\
\text { T-CHO } \\
\text { GLU } \\
\text { T-BIL } \\
\text { GOT } \\
\text { GPT } \\
\text { LDH } \\
\text { ALP } \\
\text { BUN } \\
\text { CRE } \\
\text { UA } \\
\mathrm{Na} \\
\text { K } \\
\text { C } 1 \\
\mathrm{Ca} \\
\mathrm{T}-\mathrm{ACP}\end{array}$ & $\begin{array}{l}\frac{5.34 \mathrm{~g} / \mathrm{dl}}{1.65 \mathrm{~g} / \mathrm{dl}} \\
\frac{0.45}{120 \mathrm{mg} / \mathrm{dl}} \\
226 \mathrm{mg} / \mathrm{dl} \\
1.7 \mathrm{mg} / \mathrm{dl} \\
20 \mathrm{IU} / \mathrm{L} \\
22 \mathrm{IU} / \mathrm{L} \\
159 \mathrm{IU} / \mathrm{L} \\
18.6 \mathrm{~K} . \mathrm{A} \\
\frac{106.4 \mathrm{mg} / \mathrm{dl}}{3.9 \mathrm{mg} / \mathrm{dl}} \\
\frac{19.1 \mathrm{mg} / \mathrm{d} 1}{1.3 \mathrm{mEq} / \mathrm{L}} \\
4.3 \mathrm{mEq} / \mathrm{L} \\
105 \mathrm{mEq} / \mathrm{L} \\
8.2 \mathrm{mg} / \mathrm{dl} \\
2.4 \mathrm{~K} . \mathrm{A} .\end{array}$ \\
\hline \multicolumn{2}{|l|}{ 蛋白分画 } \\
\hline $\begin{array}{l}A 1 b \\
\alpha 1 \\
\alpha 2 \\
\beta \\
\gamma\end{array}$ & $\begin{array}{r}30.0 \% \\
9.1 \% \\
17.3 \% \\
7.6 \% \\
36.0 \%\end{array}$ \\
\hline
\end{tabular}

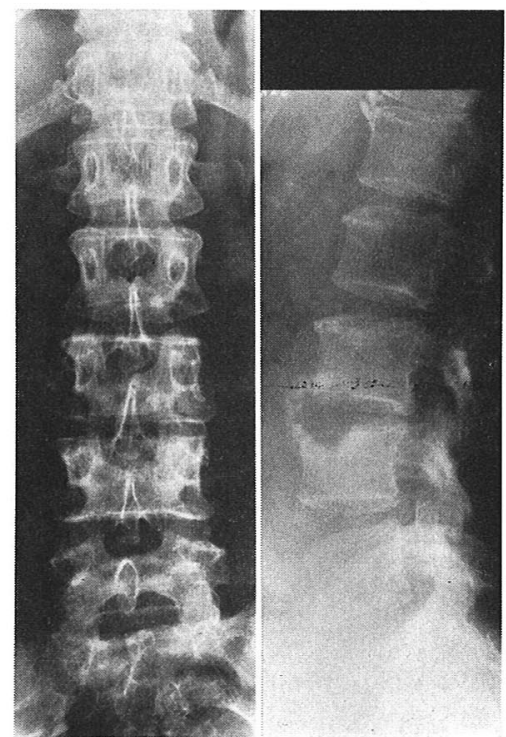

図 1 初揨㭙単純 $\mathrm{X}$ 線像

骨融解と骨棘形成を認める
るが，その範囲は椎体高の $1 / 2$ 以下である.

${ }^{99} \mathrm{~T} \mathrm{c}$ による骨シンチ及び ${ }^{67} \mathrm{Ga}$ による腫演シンチ グラムでは, 図 3 のごとく $\mathrm{L}_{3}, \mathrm{~L}_{4}$ に一致し強い集積 像学認めた.

CT 検査にて, $\mathrm{L}_{4}$ 椎体前方の骨融解像とと屯に傍 脊柱軟部陰影を認める. 両側の腸腰筋は外側に, 大動 脈，下大静脈はともに前方に圧排されており，その境 界は比較的不鮮明である。

経過：入院後の 経過は図一 4 の如くである.11月 23 日の臨床所見より化膿性疾患を疑い，左腰部に切 開を加えると，大量の膿の排出を見た．膿は悪臭を放 ち，黄緑色を呈して扣り，160 gr であった. 以後 1 日量 $100 \mathrm{gr} \sim 300 \mathrm{gr}$ の排膿があり，臨床症状も漸次 軽快したが，さらに左下腹部に，腫脹，発赤，熱感な ど熱性膿瘍の像を認めた. CT 検査にて左下腹部に cyst 形成を認め abscess 眝留が疑われた為, 12 月 6 日，切開排膿を行い $330 \mathrm{gr}$ の排膿を認めた（図

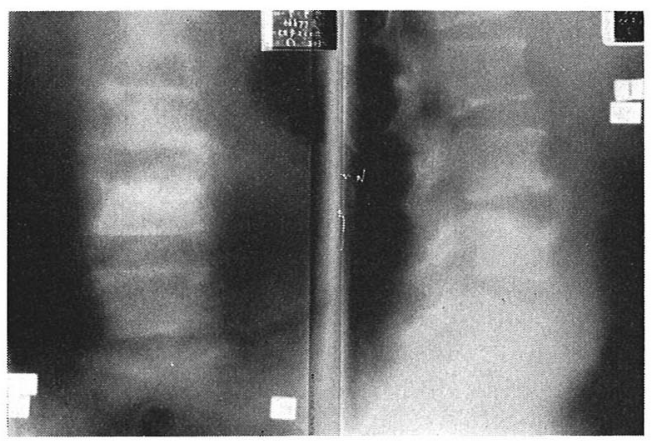

図2 断層 撮影

淡い反応性骨硬化を認める

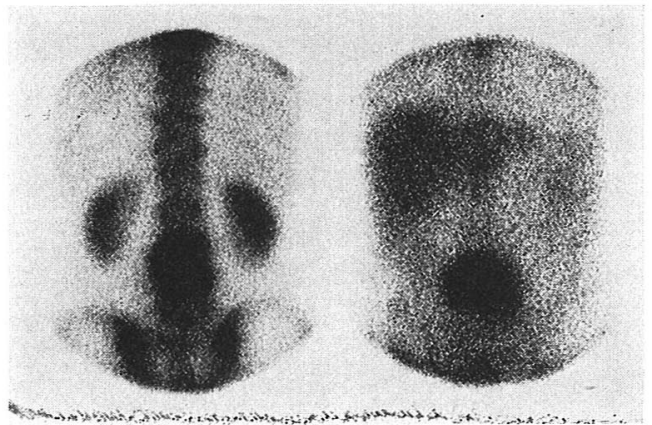

図3右：腫㿂シンチグラム 左：骨シンチグラム

$\mathrm{L}_{3} \mathrm{~L}_{4}$ に強い集積像を認める 


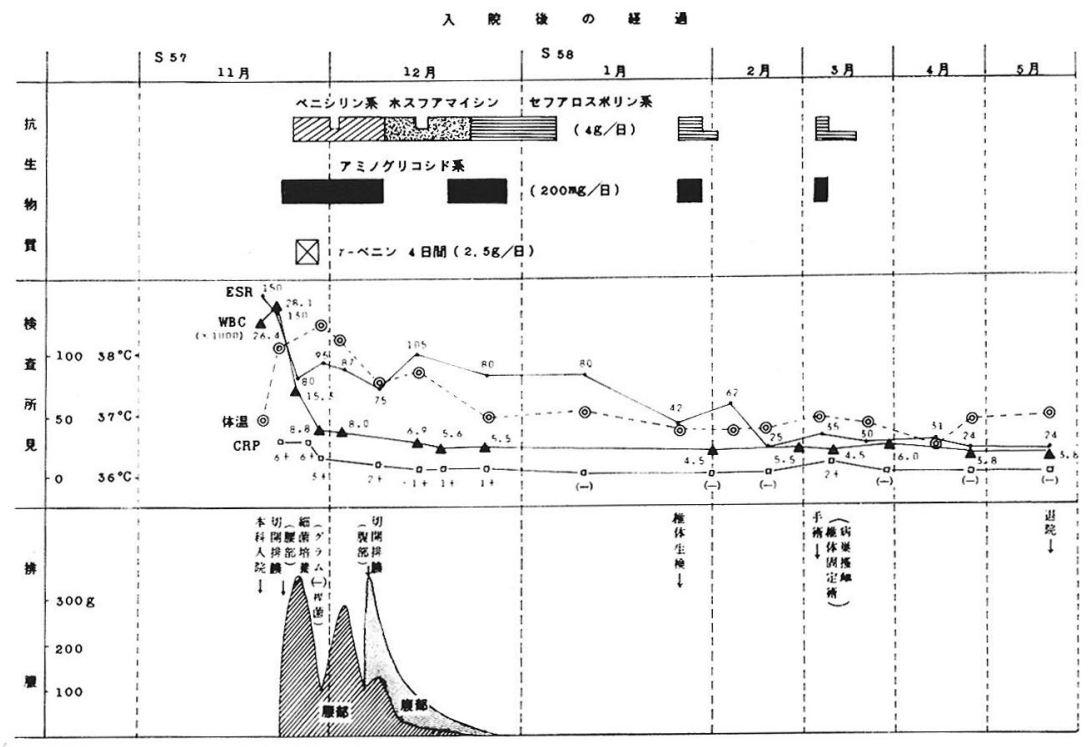

図4 入院後の経過

1 日 $100 \mathrm{gr}$ 加ら $300 \mathrm{gr}$ の大量の排膿を認ぬた。

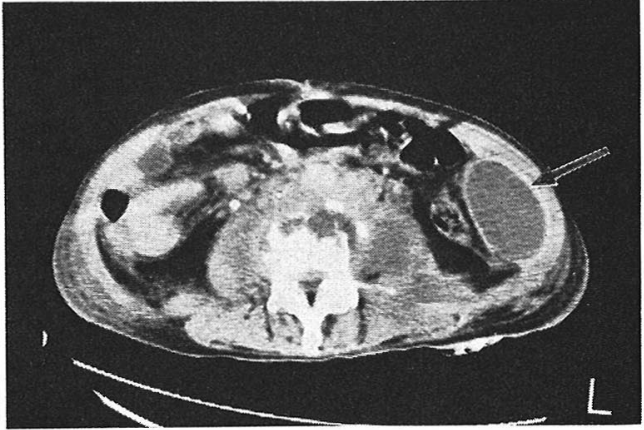

図 5 C Tスキャン

骨融解像とともと傍脊柱教部陰影を認める，矢印 は左下腹部の cyst を示す.

5 ). 図 6 は腰部, 左下腹部の膿聤の部位を示す。ま た外科で腹部内臟器官と外壁膿瘍の連絡が疑われたた め, 㾇孔造影による腰椎との関連を検索することはで きなかった，それ以後は, 排膿の経日的減少を認め, 昭和 58 年 1 月 3 日, 創闒鎖した. その間, 抗生剂及び rーグロブリン投与を行い，症状の軽快を見ているが， 確定倝断在下す為, 昭和 58 年 1 月 24 日, 椎体生検施 行. またレントゲン所見にて，化骨形成の遅延および 赤沈の中等度亢進等が認められた為, 同年 3 月 3 日, 病紧搔爬, 椎体固定術を施行した.
朖痬の部位
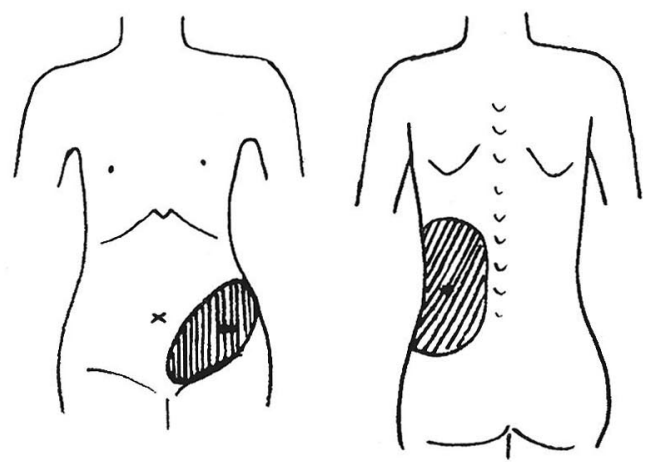

図 6 膿陽の部位

熱性膿湯であった

手術所見: $\mathrm{L}_{3}, \mathrm{~L}_{4}$ 椎体周囲は線維性に癒着が高度で 強度の炎症の痕跡をうかがわせた． $\mathrm{L}_{3 \sim 4}$ 間は空洞形成 しており周四の骨硬化は著明であった，同部に膿瘍は 認めず，軽度の肉芽組織を認めた。

光顕所見：生検時標本及び手術時慓本ともに軽度の 炎症細胞の浸潤が見られ，慢性非特異性炎症の像であ った (図一7).

細菌学的所見：膿の塗沫標本にて，グラム陰性桿菌 
表 2 脊椎カリエス, 軽移性脊椎腫場との鑑別

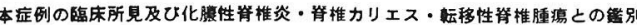

(○印 : 本应列と所見か適合するもの)

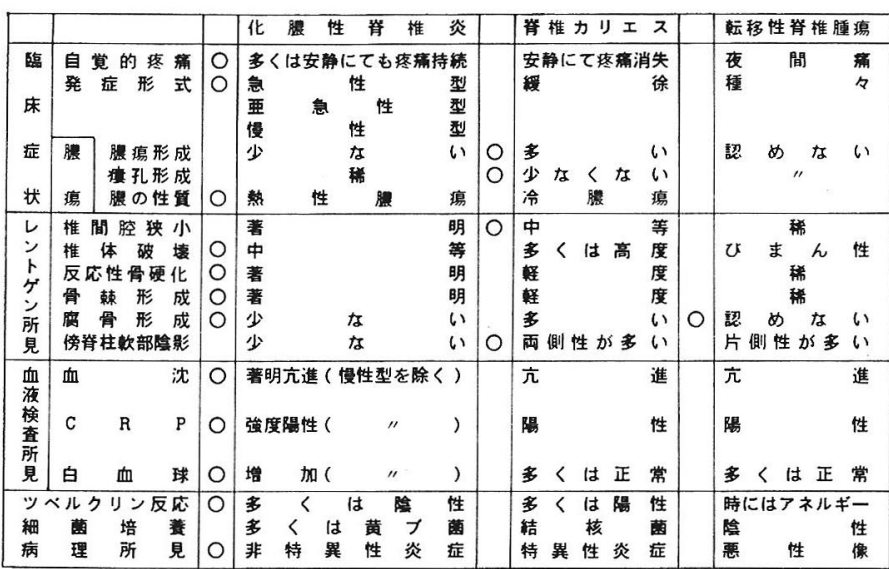

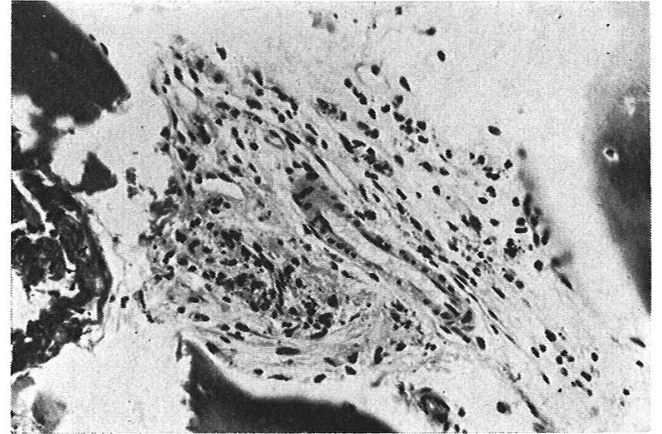

図 7 病理組織 $($ H.E. $\times 800)$

軽度の炎症細胞の浸潤が見られ，慢性非特異性炎 症の像を呈す

が認められたが，膿及び動脈血培養にて好気性，嫌気 性ともに陰性という結果となり菌の同定迄には致らな かった，結核菌については，塗沫，培養とも陰性であ った.

術後経過：経過良好で, 6 週以上にわたり, 赤沈, CRP，白血球数ともに正常值を示し，X線所見です良 好な骨癒合を見た為, 5 月 27 日退院. 現在, 一本杖に て歩行している.

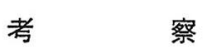

1. 鑑別診断について

本症例は，初期のレントゲン像で椎体のびまん性骨 融解像から脊椎腫湯との鑑別が必要となり，後に排
膿，瘻孔形成を認めてからは脊椎カリエスとの鑑別が 重要となった症例である（表一2）.

下出 ${ }^{7)}$ が述べている如く, 起炎菌の同定ができない 場合，病理組織所見で 化膿性脊椎炎と診断を下すの は，危険であると思われる.陳旧化した脊椎力リエス においても, 非特異性慢性炎症像を呈す事があるから である。本症例に执いては，膿瘍が熱性膿瘍である 事，レントゲン像にて比較的早期の反応性骨硬化，骨 棘形成を認める事, 血液検査所見にて赤沈, CRP, 白 血球が著明な異常值を呈した事，また同定はできなか ったが，グラム染色の塗沫標本にて多数のグラム陰性 桿菌を認めた事などから，化膿性脊椎炎との確定診断 を下してあ良いのではないかと考えている.

2. 起炎菌について

化膿性脊椎炎の確定彰断には，起炎菌の証明が必要 となってくるが，諸家の報告1446) のごとく，菌の検 出率は低い様である. 我々の渉猟し得た報告の範囲で は, 椎間板炎を含む椎体炎の本邦報告例 331 例中 92 例, $27.8 \%$ みに菌の検出がなされたにすぎない. その原因として，一つは化膿性炎症の時期にあよるの であろうが，そこには当然抗生物質による治療との関 連が出てくると思われる. その他, COLLERT ${ }^{2)}$ が指 摘する様に, より熟練した培瀁技術をもってすれば, 菌の検出率も向上するのではないかと考える。本症例 では初回排膿時, 膿の好気性及び嫌気性培養之動脈血 の好気性及び嫌気性培養を行い, いずれも陰性という 
結果であり，その時点での確定診断を下し得なかった あのである. 後に施行した椎体生検, 手術時搔爬物質 からあ菌は証明されなかった。僅かに，初回排膿時の グラム染色による塗沫標本にて多数のグラム陰性桿菌 が証明されたのみであった.

又, 感染経路についても, 血行感染の中では, 原発 巣として骨盤内臓器を重視する報告が多い，本症例に おいては，骨盤内炎症は認められなかった。

3. 膿瘍について

最近の報告では，化膿性脊椎炎における膿瘍形成， 瘦孔形成は少ないとする報告3)45) が多く，それが脊 椎カリエスとの鑑別の一つに挙げられている．統計学 的に見ると，椎間板炎を含む椎体炎の本邦報告例 331 例のうち膿瘍を認めたものは 50 例，そのうちの 32 例 は，鶴見 ${ }^{8)}$ の統計によるあのであるが 1963 年以前に 発表されたものである，一方，里見 ${ }^{6)}$ の報告をみる と，1970 年より 10 年間の 比較的最近の化膿性脊椎炎 の症例 21 例中，膿瘍形成をみたものは 7 例， $33.3 \%$ であり，比較的高率となっている．膿瘍形成の要因之 して考えられることは, 一つは起炎菌の毒力, 又一つ には治療面における問題が考慮されるべきであり，ま た生体の抵抗力にあ要因を求め得るのではないかと考 えた．先ず起炎菌に関しては，膿瘍形成した症例のほ とんどが，黄色ブドウ状球菌であり，膿瘍を認めなか った症例との差はない。ただ，本症例ではグラム陰性 桿菌であった．次に治療面に扮ける問題として，発症 より治療開始迄の期間が, 膿瘍形成症例においてやや 長いという傾向はあるが，はっきりとした差異は認め られなかった，本症例に拈いては，治療開始の遅れは 否めない. 生体の抵抗力に関しては, COLLERT ${ }^{11}$ は 82 例中 10 例, $10 \%$ に糖尿病の合併を認めたと報告し ているが, 本邦例の膿瘍形成例においては, 特別な記 載は少ない，本症例では右片麻㾇の状態であり，一般 健常者に比べては抵抗力に問題があると思われる.

4. 治療について
早期発見，早期治療を行えば，保存的治療にて治癒 が可能と考える。初期には広域スペクトルの抗生剂の 多剂併用及び $r$ グロブリン投与が効果的と思われる. しかし，遷延性の症例，再発を繰り返す例，神経症状 を呈する例などには手術的治療が必要である．本症例 屯遷延性との判断から手術施行し, 良好な骨癒合を得 た

\section{まと め}

1. 大量の排膿を認め, 起炎菌が同定できず診断に 難渋した症例を経験した.

2. 本症の膿瘍形成については, 起炎菌の問題, 治 療開始の遅延, 生体の抵抗力の低下等より生じてきた のではないかと推察される.

3. 臨床症状, レントゲン所見, 血液検査所見等よ り総合的に考察すれば，化膿性脊椎炎の診断は早期に 下し得るすのと考える。

\section{参 考 文 献}

1) Collert, S.; Osteomyelitis of the spine. Acta. Orthop. Scand., 48: 283-290, 1977.

2) Collert, S.; Chronic sclerosing osteomyelitis (Garré). Clin. Orthop., 164: 136-140, 1982.

3）国分正一：化膿性脊椎炎一䛦断と治療について 一. 臨整外, 13: 307-316, 1978.

4) 沼尾茲夫：診断にまぎらわしい化膿性脊椎炎症 例の臨床的検討. 整形 - 炎害外科, 15：956-962, 1982.

5) Ross, P. M.; Vertebral body osteomyelitis. Clin. Orthop., 118: 190-198, 1976.

6）里見和彦：化膿性脊椎炎の経験。臨整外，15： 594-600, 1980.

7）下出真法：化膿性脊椎炎の臨床像一結核性脊椎 咨との比較一. 臨床外, 13：317-322，1978.

8）鶴見寛治：化膿性脊椎炎の臨床的観察. 整形外 科, 14: 40-46, 1963 . 